Abstracta Iranica

Revue bibliographique pour le domaine irano-aryen

Volume 27 | 2006

Comptes rendus des publications de 2004

\title{
«Images de déesses ? ». Transeuphratène, 28 (2004), pp. 149-163.
}

\section{Rédaction}

\section{Q OpenEdition}

10 Journals

\section{Édition électronique}

URL : http://journals.openedition.org/abstractairanica/5759

DOI : 10.4000/abstractairanica.5759

ISSN : 1961-960X

Éditeur :

CNRS (UMR 7528 Mondes iraniens et indiens), Éditions de l'IFRI

\section{Édition imprimée}

Date de publication : 15 mai 2006

ISSN : 0240-8910

\section{Référence électronique}

Rédaction, « «Images de déesses ? ». Transeuphratène, 28 (2004), pp. 149-163. », Abstracta Iranica [En ligne], Volume 27 | 2006, document 97, mis en ligne le 02 janvier 2007, consulté le 25 septembre 2020. URL : http://journals.openedition.org/abstractairanica/5759; DOI : https://doi.org/10.4000/ abstractairanica. 5759

Ce document a été généré automatiquement le 25 septembre 2020.

Tous droits réservés 


\section{«Images de déesses?».}

$$
\begin{aligned}
& \text { Transeuphratène, } 28 \text { (2004), } \\
& \text { pp. 149-163. }
\end{aligned}
$$

\section{Rédaction}

1 Il existe en Syrie du Nord à l'époque achéménide des terres cuites très particulières qui montrent une femme cavalière assise à califourchon ou en amazone, entière ou réduite à un buste. Elle est souvent accompagnée de petits visages qui ressemblent à des enfants mais qui parfois sont barbus. Ces visages barbus font inévitablement penser aux cavaliers dits " perses ». Le corpus présenté ici comporte 30 figurines, parmi lesquelles 8 reconstitutions sont incertaines. Les représentations les plus anciennes de personnes - elles sont masculines - montant un animal en amazone proviennent de Syrie et remontent au $3^{\mathrm{e}}$ millénaire. Plus tard, une cavalière en amazone est connue en Grèce, un cavalier à Chypre. Néanmoins, l'origine de nos cavalières est incertaine, elle pourrait être simplement locale. Il est certain que ces objets servaient dans les pratiques cultuelles quotidiennes et appartenaient à la piété populaire. Cette remarque ne résout pas la question de savoir qui est représenté. À mon avis, il s'agit plutôt d'une déesse que d'une prêtresse.

\section{INDEX}

Thèmes : 3.2.1. Elam 


\section{AUTEURS}

\section{RÉDACTION}

Directeur de la revue et secrétariats (Paris et Téhéran) 